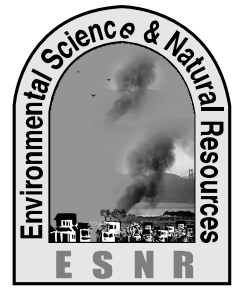

J. Environ. Sci. \& Natural Resources, 5(1): 193 - 198, 2012

ISSN 1999-7361

\title{
Impacts of Flood on Crop Production in Haor Areas of Two Upazillas in Kishoregonj
}

\author{
M. N. H. Khan ${ }^{1}$, M. Y. Mia ${ }^{2}$ and M. R. Hossain ${ }^{2}$ \\ ${ }^{1}$ Department of Environmental Science, Bangladesh Agricultural University, Mymensingh \\ ${ }^{2}$ Department of Environmental Science and Resource Management \\ Mawlana Bhashani Science and Technology University, Tangail
}

\begin{abstract}
Haor is basin like structure where water remains either stagnant or in flash flooding condition during the months of June to November. In Bangladesh, haor areas are covered by Boro rice and produce a large amount. Severe flood damage this boro crop, so that the study was conducted to know the land use pattern and impact of flood on boro rice production. Both primary and secondary data were used for the study. Primary data were collected as survey sampling method (questionnaire, FGD, PRA etc.) from Itna and Mithamoin Upazilla where total respondents were 119. Secondary data were collected from Upazilla Administrations and Department of Agricultural Extension. Mainly descriptive statistics were employed to analyzing the data using MS Excel and SPSS. Most of the respondents were farmer. Major portion of their cultivable land are low land. Rabi is the only cropping season and during Kharif -1 , and Kharif - 2 lands became fallow due to inundate on flood water. In rabi season boro is the main crop and damaged by flash flood due to unavailability of controlling measures. Flood control measures would be taken to prevent huge loss of boro rice.
\end{abstract}

Key words: Crop production, Flood, Haor area

\section{Introduction}

Bangladesh is the most vulnerable area to several natural disasters and every year natural calamities upset people's lives in some parts of the country. The major disasters concerned here are the occurrences of flood, cyclone and storm surge, flash flood, drought, tornado, riverbank erosion and land slide (UNEP, 2001). Some 30 to 35 percent of the total land surface of the country is flooded every year during wet monsoon (Milliman et al., 1989). These normal floods are considered a blessing for Bangladesh providing vital moisture and fertility to the soil through the alluvial silt deposition (UNEP, 2001).

There are many haors (basin like structure) in Bangladesh where water remains either stagnant or in flash flooding condition during the months of June to November. Geographically, most of the haors are situated in seven districts, Sunamganj, Kishoreganj, Netrokona, Sylhet, Habiganj, Maulavibazar and B. Baria of the North-East Bangladesh (Alam et al., 2010). Almost $80 \%$ of this haor areas is covered by boro rice, while only about $10 \%$ area is covered by $\mathrm{T}$. aman production (Huda, 2004). In the haor areas, hybrid rice is also grown (Das, 2004). In terms of ecosystem, crop production practices, economic activities and all over livelihood of the farmers of haor areas are quite different from those of the other parts of the country (Alam, et al., 2010).

Haor in Kishoregonj district is very much important in geo-physical, economic, social and cultural point of view (Kishoregonj Zilla, 1993). Among 13 Upazillas of this district four (Itna, Mithamoin, Austogram and Nikli) are fully and five (Tarail, Karimgonj, Bajitpur,
Kuliarchar and Bhairab) are partially bounded by hoar. Total number of haor in the district is 85 with an area of 75000 hectare (DAE, 2003). These haor have a great significance to the agricultural production of the district (DAE, 2010). Large amount of rice produce in these haor areas and it is of food surplus (DAE, 2010). People of the Itna and Mithamoin upazilla of the Kishoregonj district is mainly farmer and is fully dependent on their agricultural land (UAI, 2005). Boro is their main crop, but some other rabi crop (wheat, potato, muastard seed etc.) are also grown.

Early flood, hailstorm and drought are the main constraints to grow modern boro rice (Alam et al., 2010). Though flood is the common phenomenon in the haor areas, people have had an experience about the seasonal and flash flood with its frequency and magnitude (Pavel et al., 2007). But now a days they are unable to predict about the flood due to different development activities in the upstream, embankment and river filling as well as change of river flow (Pavel et al., 2007).

Recent years flood attack unpredictably and severely in the haor areas and damage agricultural crop with a large amount. This agricultural loss fall a serious impact on national economy. Last several years after liberation in 1974, 1988, 1998, 2004 (UAI, 2005) and 2010 flood attacks severely in this region and damage huge amount of agricultural production.

Since the cropped area is being continuously shrinking over time leading to serious challenge towards increasing productivity and of attaining selfsufficiency in food production for the land scarce economy of Bangladesh, it needs to explore the crop 
production constrain of the large haor areas. Therefore, present study was conducted with the following objectives:

$>$ To know the overall land utilization pattern and

$>$ To understand the potential impacts of flood on agriculture especially on boro crop production.

\section{Materials and Methods}

\section{Study area}

The study was conducted on Itna and Mithamoin Upazilla in Kishoregonj District. Itna Upazila is located $24^{0} 23^{\prime}$ north to $24^{0} 38^{\prime}$ north latitude and $90^{\circ} 46^{\prime}$ east to $91^{0} 14^{\prime}$ east longitude with an area of $401.94 \mathrm{sq} \mathrm{km}$. Mithamoin Upazila is located $24^{0} 13^{\prime}$ north to $24^{0} 31^{\prime}$ north latitude and $90^{0} 56^{\prime}$ east to $91^{0} 16^{\prime}$ east longitude with an area of $222.92 \mathrm{sq} \mathrm{km}$.

\section{Source of data}

Both primary and secondary data were used for the study. Primary data were collected through survey sampling method (questionnaire, FGD and PRA) from Itna and Mithamoin Upazilla. Secondary data were collected from different organization viz. Upazilla Agriculture office, Agriculture Extension office, office of the Deputy Commissioner etc.

\section{Sample size}

Primary data were collected from 119 respondents (57 from Itna and 62 from Mithamon Upazilla) of different occupation. These samples were selected randomly for the study.

\section{Data collection method}

Primary data from respondents' were collected using questionnaire interview, Participatory Rural Appraisal (PRA) tool such as Focus Group Discussion (FGD) and cross-check interviews with key informants.
A set of interview schedule was designed for the study. The questionnaire was designed both close and open form of questions. The interview schedule was developed in logical sequence, so those local people and farmer could answer systematically. The questionnaire interviews were conducted in October 2010 at the haor side to the randomly selected unions of Itna and Mithamon Upazilla. Each question was explained clearly and asked systematically as for their sound understanding. PRA tool such as Focus Group Discussion (FGD) was conducted with local people including farmer, fisherman and day. A total of two (02) FGD sessions was conducted, where each group size of FGD was 8 and 12 participant. After collecting data through questionnaire interviews and FGD, cross-check interview were conducted with key information towards the key informants at their office and/or houses.

\section{Data processing and analysis}

Mainly descriptive statistics were employed in analyzing the data. The collected data were verified to eliminate errors and inconsistencies. Any kind of inconsistencies in the collected data were searched and avoided from the relevant data. Data were processed and entered into computer using MS Excel (Microsoft Excel) and SPSS (Statistical Package for Social Science) programming and analyzed as per objectives by tabular and graphical method. The local units of data were converted into international units before analysis.

\section{Results and Discussion}

\section{Selected characteristic of the respondent}

For conducting the study 119 respondents (57 from Itna and 62 from Mithamon Upazilla) were selected randomly. They were classified into seven occupation levels. They were farmer $(30.25 \%)$, fisherman $13.45 \%$, farmer cum fisherman $33.61 \%$, businessman $8.40 \%$, service holder $7.56 \%$, boatman $4.20 \%$ and day labour $2.52 \%$ (Table 1).

Table 1. Primary occupation of the respondents in Itna and Mithamoin Upazilla

\begin{tabular}{|l|c|c|c|c|c|c|}
\hline \multirow{2}{*}{ Occupation } & \multicolumn{2}{c|}{ Itna $(\mathrm{n}=57)$} & \multicolumn{2}{c|}{ Mithamoin $(\mathrm{n}=62)$} & \multicolumn{2}{c|}{ Total $(\mathrm{n}=119)$} \\
\cline { 2 - 8 } & Number & $\%$ & Number & $\%$ & Number & $\%$ \\
\hline Farmer & 17 & 29.82 & 19 & 30.65 & 36 & 30.25 \\
\hline Fisherman & 7 & 12.28 & 9 & 14.52 & 16 & 13.45 \\
\hline Farmer cum Fisherman & 17 & 29.82 & 23 & 37.10 & 40 & 33.61 \\
\hline Businessman & 7 & 12.28 & 3 & 4.84 & 10 & 8.40 \\
\hline Service holder & 4 & 7.02 & 5 & 8.06 & 9 & 7.56 \\
\hline Boatman & 3 & 5.26 & 2 & 3.23 & 5 & 4.20 \\
\hline Day labor & 2 & 3.51 & 1 & 1.61 & 3 & 2.52 \\
\hline
\end{tabular}




\section{Land type of the study area}

Most of the lands in study area are low land (Fig. 1). In Itna Upazilla there is no high land and medium high land. These low lands are flooded every year in monsoon season. Seasonally flooded land is suitable for rice cultivation (Bhuiyan, 2006a).

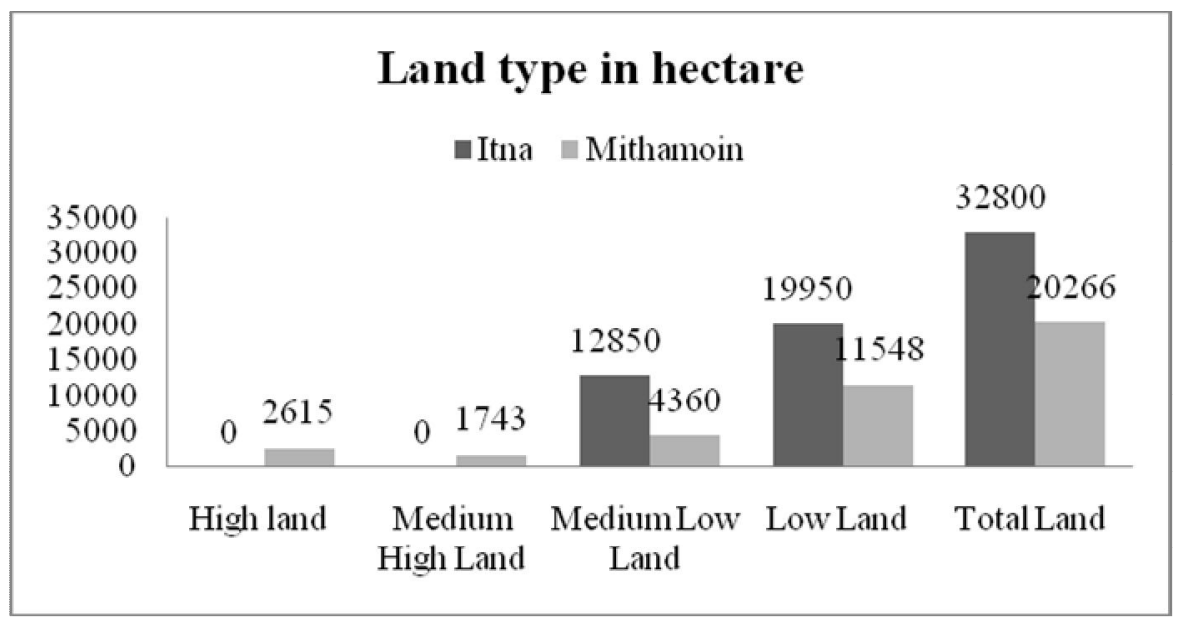

Fig. 1. Land type (in hectare) of Itna and Mithamoin Upazilla (Source: DAE, 2010 and UAM, 2006)

\section{Cultivable land}

Among total lands almost all are cultivable. Cultivable land in Itna and Mithamoin Upazilla are 28450 and 18816 hectares respectively. Only 23 hectares are completely barren in Mithamoin Upazilla and in Itna is 17350 hectares (Fig. 2). In these cultivable lands mainly boro rice produce in rabi cropping season.



Fig. 2. Cultivable land (in hectare) of Itna and Mithamoin Upazilla (Source: UAI, 2005and UAM, 2006) 


\section{Cropping pattern}

The existing cropping pattern of Itna and Mithamoin Upazilla are shown in Table 2. It shows that boro is the main crop in both upazillas of the study area. Some other rabi crops are also grown. After rabi season rest of the year, Kharif -1 , Kharif -2 (this time land cannot be used for cultivation), and cultivable land became fallow. During this period cultivable lands inundate under flood. In deeply flooded lands, single cropping of broadcast Aman (deepwater rice) in Kharif, or Boro in rabi, is the common practice (Bhuiyan, 2006b).

Table 2. Cropping pattern in Itna and Mithamoin Upazilla

\begin{tabular}{|l|l|l|l|l|l|}
\hline \multicolumn{3}{|l|}{ Itna Upazilla } & \multicolumn{4}{c|}{ Mithamoin Upazilla } \\
\hline Rabi & Kharif - 1 & Kharif - 2 & Rabi & Kharif - 1 & Kharif - 2 \\
\hline Boro & Fallow & Fallow & Boro & Fallow & Fallow \\
\hline Wheat & Fallow & Fallow & Wheat & Fallow & Fallow \\
\hline Potato & Fallow & T-aman & Potato & Fallow & Fallow \\
\hline Mustard /Boro & Fallow & T-aman & Mustard /Boro & Fallow & Fallow \\
\hline Vegetables / Boro & Fallow & Fallow & Vegetables / Boro & Fallow & Fallow \\
\hline
\end{tabular}

(Source: UAI, 2005and DAE, 2010)

\section{Flood types}

In the study areas mainly flash flood affect severely, said $70 \%$ of the respondents (Fig. 3). Among the respondents $19 \%$ and $11 \%$ said rainfed flood and river flood damage their boro crop respectively. Crop damaged in these haor areas by flash flood due to the physical setting of the haor area. Flash floods often cause considerable, localized damage to crops, particularly in the north, northeast and eastern part of the country (Islam, 2006).

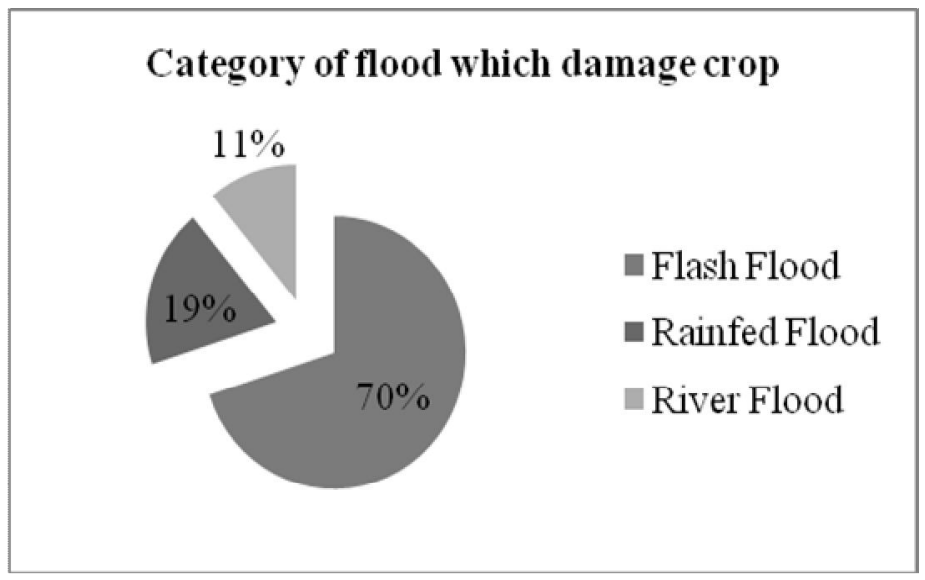

Fig. 3. Types of flood which damage crop.

\section{Affected land area}

Most of the respondent, $84.03 \%$, said that flood inundate both the low and medium low land and damage crops. While $10.92 \%$ said the low land inundate only (Fig. 4). The flood depth to which the land is normally inundated ranges from 30 to $250 \mathrm{~cm}$, but in some areas, particularly in depressions and haors, it may reach to $500 \mathrm{~cm}$ (Islam, 2006). Most of the lands in the study area are low and medium low land (Fig. 1), so these lands are mainly affected by flood. 


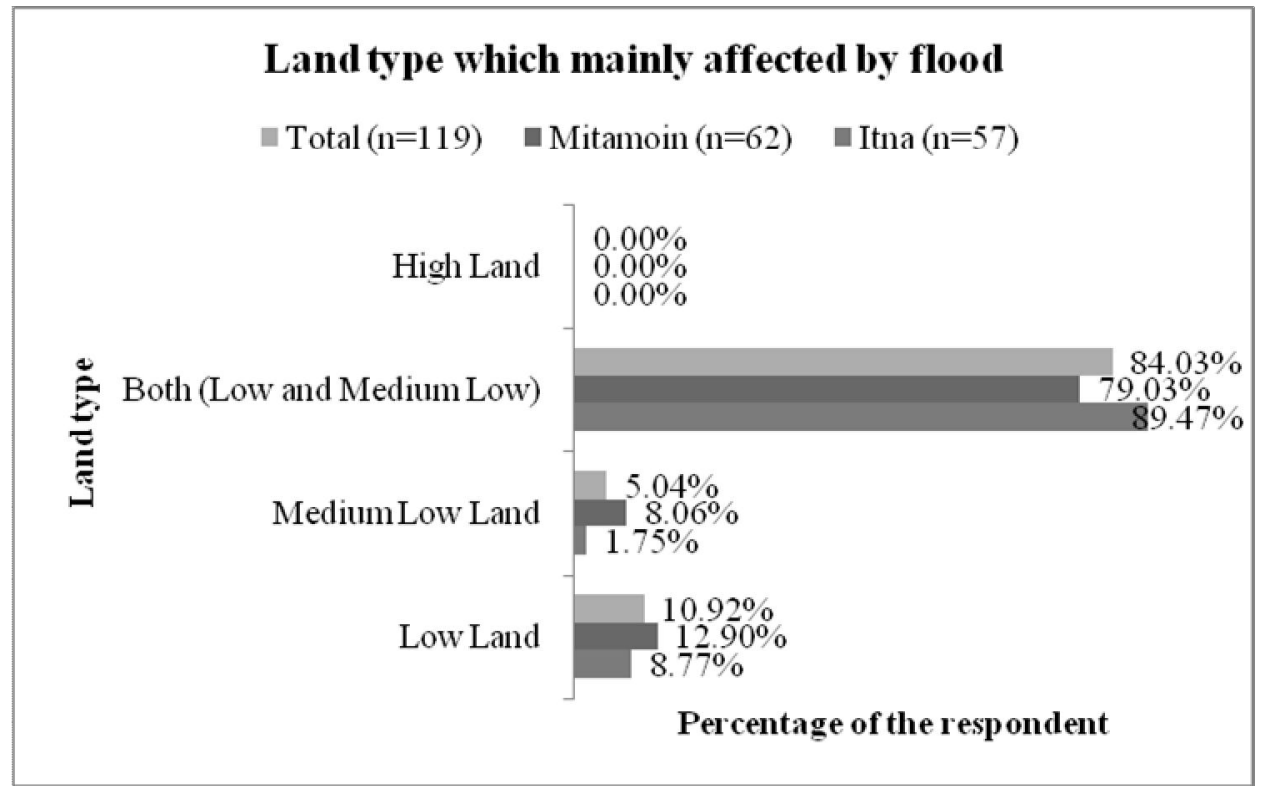

Fig. 4. Land type which mainly affected by flood.

\section{Types of crop damage}

From the study $96.64 \%$ of the total respondents said that boro crop mainly damaged by flood (Fig. 5). Lands of the study area are mainly single cropping.
Agricultural activities are done mainly in rabi season and boro is the main rabi crop (Table 2). So flood damage mainly and/or only boro.

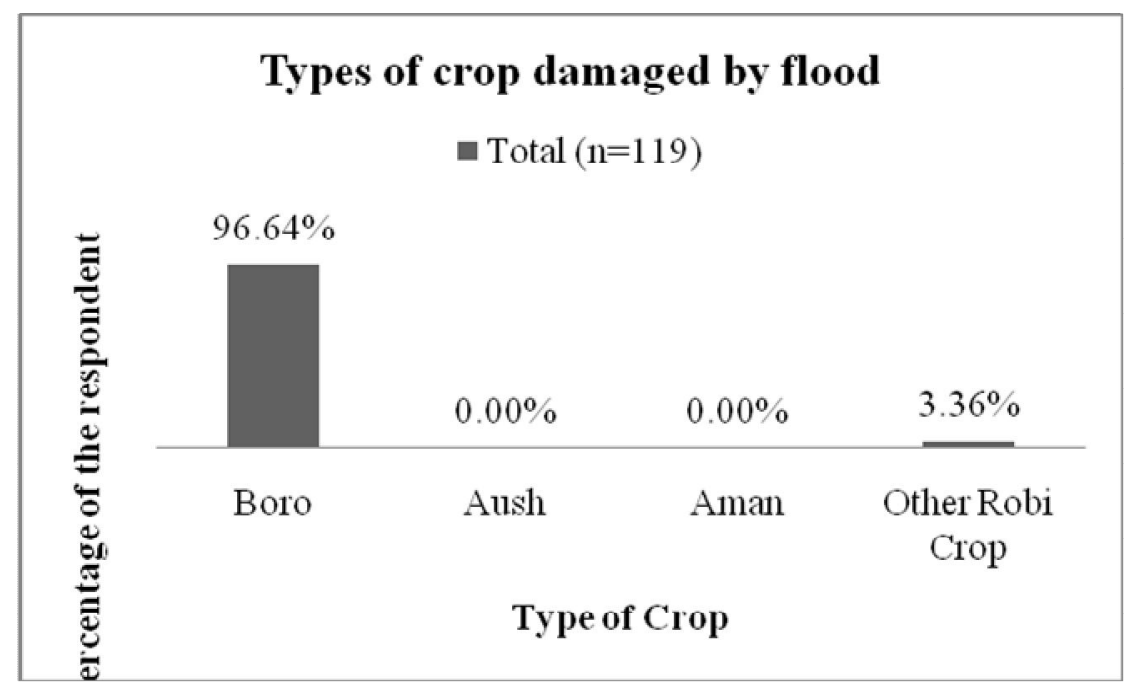

Fig. 5. Types of crop damaged by flood.

\section{Causes of boro damage}

From the study $57.14 \%$ of the respondents, where major portion are farmer, said that all of these factors, late sown, unavailability of flood control technologies (e.g., embankment, levees etc.), river filling by siltation are collectively involved their boro crop damage (Fig. 6). Unavailability of seed, diesel, fertilizer etc. influences farmers to late sown their crops as a result flood attack before or at ripening period 


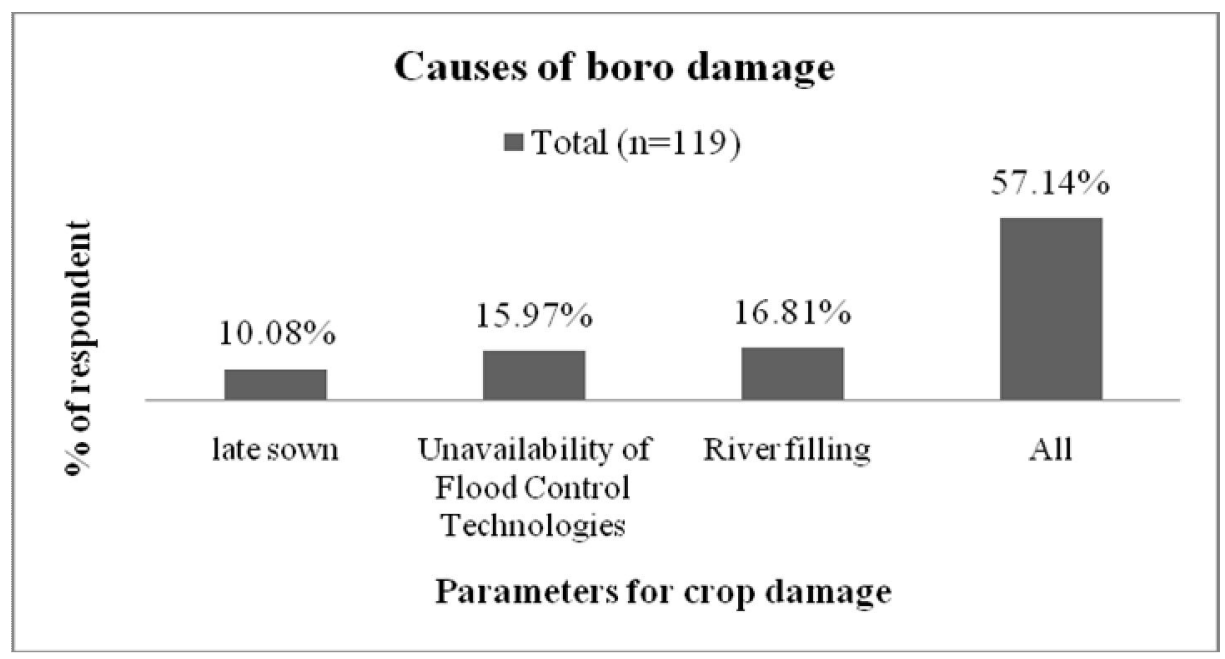

Fig. 6. Causes of boro rice damage.

\section{Conclusions and Recommendations}

The study elucidate that the Haor area is very important for the production of rice, especially boro. Flood is the common phenomena in the haor areas but in severe it damage crops. When rice damage by flood of this areas it falls negative impacts on national economy as well as on food security. In these low land haor areas flood cannot be prevent as a whole. But the loss of damage by flood can be minimized. The following measures would be suitable to mitigate flood's impacts on crop damage.

- Sustainable flood control measures like embankment, levee, river dredging etc. should be taken as early as possible.

- Ensure the availability of seeds, fertilizer, diesel and electricity at the beginning of the rabi season.

\section{Acknowledgements}

The authors are grateful to the respondents' of Itna and Mithamoin Upazilla for their cordial cooperation.

\section{References}

Alam M. S., Quayum M. A. and Islam M. A. 2010, Crop Production in the Haor Areas of Bangladesh: Insights from Farm Level Survey, The Agricultriests, 8 (2): 88 - 97.
Bhuiyan N. I., 2006a. Agricultural land, Banglapedia: National Encyclopedia of Bangladesh, Asiatic Society of Bangladesh.

Bhuiyan N. I. 2006b, Cropping pattern, Banglapedia: National Encyclopedia of Bangladesh, Asiatic Society of Bangladesh.

DAE. 2003. Annual Report: 2002 - 2003, Department of Agricultural Extension, Kishoregonj.

DAE. 2010. Annual Report: 2009 - 2010, Department of Agricultural Extension, Kishoregonj.

Das, D. C. 2004. Experience with Modern and Hybrid Rice varieties in plain land Ecosystem in the Mymensingh Region, Proceedings on Twentieth National Workshop on Rice Research and Extension in Bangladesh, Bangladesh Rice Research Institute, Gazipur-1701, pp: 19-21

Huda, M. K. 2004. Experience with modern and hybrid rice varieties in haor ecosystem: Emerging Technologies for Sustainable Rice Production, Twentieth National Workshop on Rice Research and Extension in Bangladesh. Bangladesh Rice Research Institute, Gazipur-1701, pp: 19-21

Islam M. S. 2006, Environmental issues related to agriculture, Banglapedia: National Encyclopedia of Bangladesh, Asiatic Society of Bangladesh.

Kishoregonj Zilla. 1993. History of Kishoregonj, Kishoregonj Zilla, Itihas Pronayon Committee/ Prokalpa, Kishoregonj. 